\title{
Actual problems and limiting factors in the development of the Russian military-industrial complex
}

\author{
Elena Gregova ${ }^{1,{ }^{*}}$, Irina Tulyakova ${ }^{2}$, and Victor Dengov ${ }^{2}$ \\ ${ }^{1}$ University of Zilina, Faculty of Operation and Economics of Transport and Communications, \\ Department of Economics, Univerzitna 1, 01026 Zilina, Slovakia \\ ${ }^{2}$ Saint Petersburg State University, Faculty of Economics, Department of Economics \& Economic \\ Policy, University embankment 7-9, 199034, St Petersburg, Russia
}

\begin{abstract}
.
Research background: The completion of the ideological confrontation of socio-economic systems that occurred in the early 90s of XX century after the collapse of the USSR did not radically affect the development of the global defense industrial complex (DIC). Taking into account the place and role of national DICs in the economies of the world's leading powers, we can only talk about the modification of their development in the new historical conditions. The defense industry complex in Russia, as before in the USSR, is one of the priority areas of the country's development.

Purpose of the article: The aim of the article was to study the current state of the Russian DIC, to analyse problems, limitations and prospects for its development. The hypothesis was put forward that the condition of the Russian DIC is currently determined by the whole complex of factors, both internal and external, and therefore the solution of these problems should also be comprehensive.

Methods: The study was based on statistical analysis of information from both official databases (SIPRI, World Bank, Federal Government Statistics Service) and other open sources.

Findings \& Value added: The analysis showed that all corporations of the Russian DIC have positive dynamics in the value of their assets and generally demonstrate good financial stability under difficult external and internal economic and political conditions. At the same time, a number of problems requiring prompt resolution pose a threat to the successful development of the Russian defense industry in the near and distant future. The scientific value of research is determined by the comprehensive approach itself.
\end{abstract}

Keywords: defense industrial complex; limiting factors; state defense order

JEL Classification: $F 51 ; H 56$

${ }^{*}$ Corresponding author: elena.gregova@,fpedas.uniza.sk 


\section{Introduction}

The collapse of the USSR in 1990s put an end to the ideological confrontation between the two social and economic systems. Arms race and mutual containment policies forced countries to spend enormous material, financial, human and other resources. The end of Cold War raised hopes for disarmament, military spending cut, economy restructure and redirection of spending from the military to the civilian sector. Unfortunately, those hopes didn't come to fruition. The global confrontation between the two systems, two military blocs (NATO and the Warsaw Pact) has been replaced by numerous regional military conflicts around the world, requiring more and more modern weapons to support them. The confrontation between the major world powers such as the USA, Russia, China and the EU is still on the agenda. Although the ideology took a back seat, economic aspects of the conflict between the superpowers, which, in our opinion, indirectly reflects competition for limited resource, has not made the competition less fierce or less global. That is why, every world power must develop, strengthen, and modernize its military production regardless of the impact (positive, negative or indefinite) military expenditures may have on the economic development [1-3].

The authors of this article (each to a different extent) have long been involved in the analysis of the development and modernization of both Russia's defense industrial complex (DIC) and its segments [4-10]. Armaments 2020 priority procurement program [11-12] provided a strong impetus to the growth and modernization of Russia's defense industry, but it also revealed some problems in its development as well as different kinds of limitations [13].

\section{Methodology, databases and analytical sources of research}

The analysis of the problems of Russia's defense industrial complex was based on a preliminary study of regulatory documents, state programs, and government orders. We assessed the status of their implementation and effectiveness, organizational changes and location of management units.

The information provided by different national and supranational research institutes such as Russian Federal State Statistics Service (Rosstat), World Bank Open Data from The World Bank, the official website of the President of Russia, Russian News Agency TASS served as the data base for the analysis and assessment of current condition of the Russia's DIC [1417]. Research papers by Russian and foreign scholars, regulatory legal acts related to the discussed topic, information and analytical reports of various organizations provided analytical framework for our research [18-25]. In this paper statistical methods and system analysis method are used as analysis tools.

\section{Results and discussion}

Financial stability and stable development of Russia's DIC is directly linked to Defense Procurement and Acquisition. Implementation of Armaments 2020 priority procurement program led to the rapid growth of both State Defence Order (SDO) and defense budget of the Russian Federation. Considering the current political situation, there is a prospective growth in the given sector. It should be noted, however, that despite the increased growth rate of defense industry since the implementation of Armaments 2020 priority procurement program, a number of problems, which limit the development of Russia's DIC, have appeared. Among these limitations are: scientific and technological lags, insufficient funding of $\mathrm{R} \& \mathrm{D}$, outdated equipment (heavy wear and underused of equipment), recruitment problems (lack of narrowly specialized personnel), delays in conclusion of SDO contracts, 
pricing issues, conversion and diversification of military production, pressure of sanctions, companies' dependence on import, companies' dependence on export of military equipment. We will consider these factors further.

\subsection{Scientific and technological lags, insufficient funding of R\&D}

Outdated and worn-out equipment as well as technological lag undoubtedly lead to a lower quality of products and, thus, to the loss of competitiveness of defense industry production. Therefore, a large share of products cannot compete with the same products in the global market and is in demand only among local customers in separate market niches: military orders and projects, which are oriented toward the local market.

According to Ministry of Defence, there are 10 crucial technological areas which play a pivotal role in ensuring a high quality of military products and their competitiveness. They include: new material technologies, microelectronic, nanoelectronic, radio-electronic, laser, electro-optical, computer, propulsion systems; industrial equipment; unique experimental testing facilities; nuclear technology. In terms of nuclear and laser technologies Russia stands on the same level as the USA [18].

Russia's position in the market of high-technology products and services can be assessed on the basis of analysis of defense industry priority areas which include: aircraft industry, space industry, arms industry and shipbuilding [19].

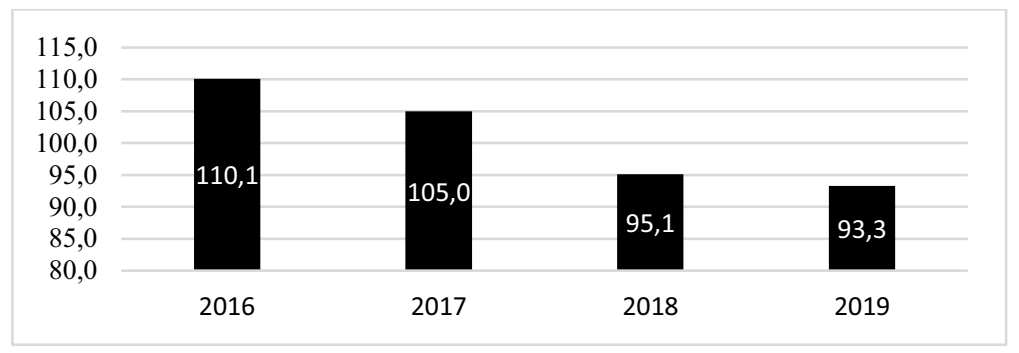

Fig. 1. Production index for high-tech economic activities, $\%$ to the corresponding period of the previous year (Compiled according to [14])

The figure 1 shows negative dynamics in production index of high-tech economic activities, which include the production of electronic and optical products, aircrafts, including space, electrical products, and industrial equipment. The essential part of country's scientific and technical capabilities is state-owned. However, the government does not provide support to $\mathrm{R} \& \mathrm{D}$ priority areas, in which Russia can become more competitive. Besides, it is necessary to focus on the production, which is characterized by the highest R\&D intensity and innovation of global significance, because the competitiveness of goods depends on their novelty and systematic development. According to World Bank (fig.2), the share of R\&D costs to GDP accounted for $1.10 \%$ in 2017 [26].

For comparison, we show data for other countries. In the USA for 2017, the share of R\&D expenditures in GDP is 2.8\%. In Germany - 3.03\%, China - 2.12\%, Japan - 3.2\%, South Korea $4.5 \%$, Israel $-4.5 \%$. Innovation activity of defense industry enterprises remains low: the share of $\mathrm{R} \& \mathrm{D}$ in the overall volume of work of defense industry accounts for only $10 \%$. Along with aging of equipment and depreciation of assets, it hinders modernization and resolution of the competitiveness problems, reduces enterprises efficiency [20].

Substantial increase of R\&D funding will help resolve a number of problems: low profitability of SDO, the risk of reduction of protectionism in the military industry, replacement of some defense industry products by imported goods, the risk of loss of crucial 
military-technical cooperation markets, increase in competitiveness of other foreign manufacturers which produce military equipment.

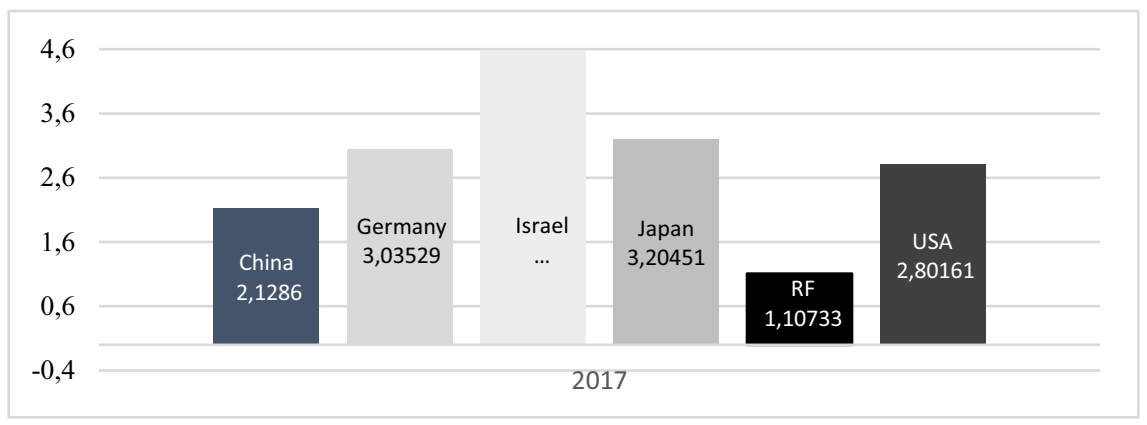

Fig. 2. Share of R\&D expenditures in GDP, \% (Compiled by the authors based on [15])

It's worth paying attention to how the share of investment in the production of ships, aircrafts, spacecrafts and other vehicles changed in fixed capital investment (fig 3). There is a downward trend which testifies to the insufficient funding for the development of technology.

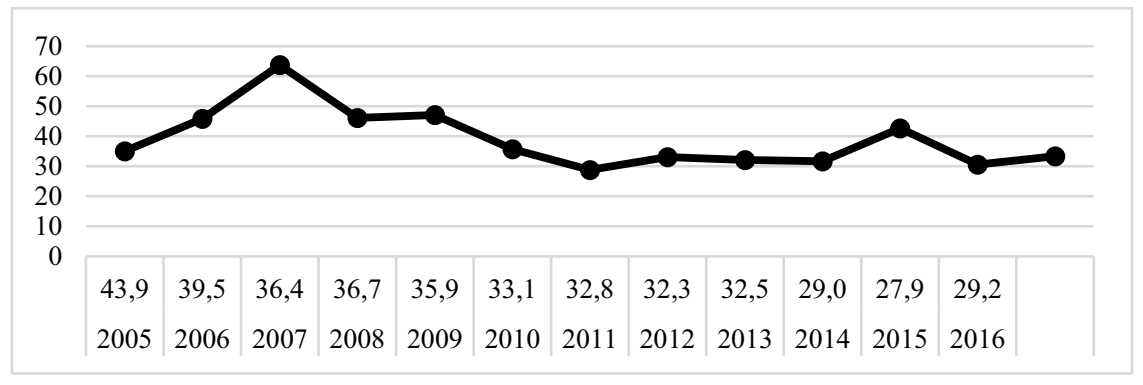

Fig. 3. The share of investments in the production of ships, aircraft and spacecraft and other vehicles in the total investment in fixed assets, \% (Compiled by the authors based on [14])

The success of the strategy that will ensure the sustainable development of Russia's DIC prior to 2025 will be determined by the following factors:

- the execution of Armaments priority procurement program for 2007-2015 and subsequent programs for 2020 and 2027 without violating their terms, volume and nomenclatures;

- a $15 \%$ increase of the share of Russian military aircrafts (front-line bomber, jet trainers, unmanned aerial vehicle) in the global market;

- a 20-30\% increase of the share of Russian military transport aircrafts in the global market;

- sustenance of a $20 \%$ share of Russian warships and naval equipment;

- insurance of Russia's presence in land weapons market, including anti-aircraft warfare and radio-electronic systems of various applications.

- significant growth of technology and emerging technology products of non-military nature produced by Russia's DIC.

\subsection{Outdated hardware}

Today, Russia faces the problem of underuse and aging equipment. It is characteristic of all post-Soviet Russian industry. The renewal of fixed assets plays a significant role in operation and development of the enterprise. To help companies ease the burden of permanent costs due to worn out assets, it is necessary to ensure careful maintenance and timely updating of equipment and structures. We will show the official Rosstat data on deterioration rate of Russia's fixed assets. 
The figure 4 shows how the deterioration rate had been increasing for 8 years. In 2014, it accounted for $49.4 \%$, then there was some improvement. However, equipment wear coefficient in Russia is high, which undoubtedly affects the operation of enterprises.

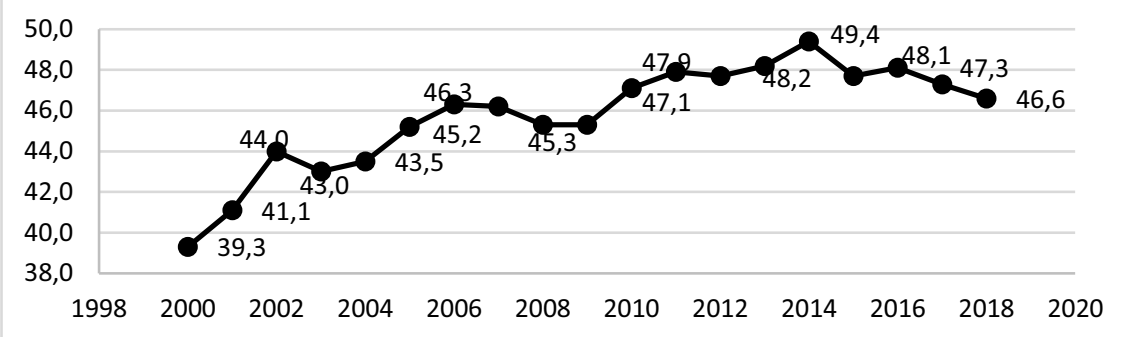

Fig. 4. The degree of wear of fixed assets in the RF end of the year,\% (Compiled by [14])

Note that at the end of 2018, the degree of depreciation of fixed assets relative to 2014 decreased and amounted to $46.6 \%$.

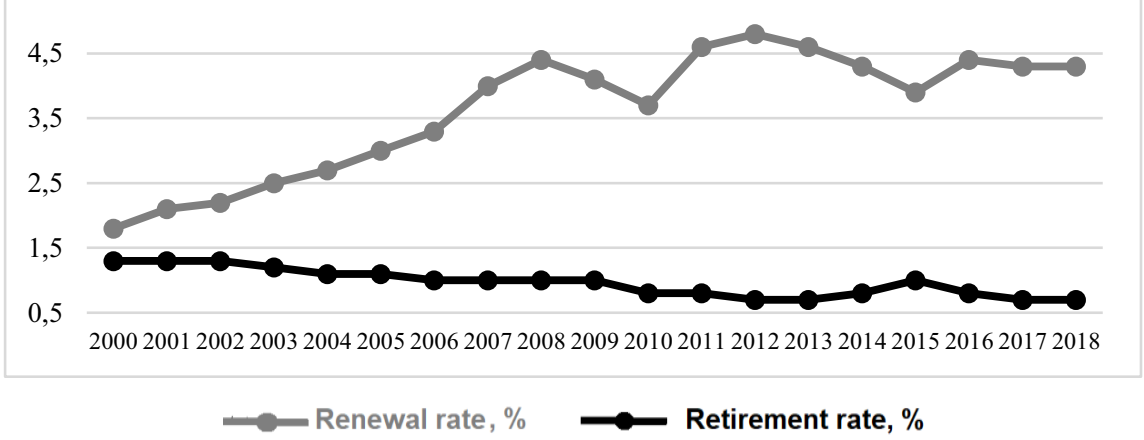

Fig. 5. Renewal rate and retirement rate of fixed assets in the Russian Federation at the end of the reporting year, \% (Compiled according to [14])

Let us also look at the figure 5 which shows the dynamics of coefficient of renewal and retirement rates of fixed assets. On the basis of presented data, we can conclude that the enterprises use old and worn-out equipment, since the wear coefficient is rather high. Meanwhile, coefficient of renewal has not changed for the past 10 years, and retirement rate is only decreasing. Thus, the enterprises use old fixed assets, which are not renewed by the new ones. Of all the machinery the worn-out equipment with the age of more than 20 years accounts for $80 \%$, equipment under 10 years - less than $20 \%$. Depreciation of industrial plant in different sectors of defense industry accounts for 60 to $82 \%$, machinery equipment and bench test facilities are not renewed, many constructions and utility lines fail and require major repair [20].

\subsection{Recruitment problems}

Another problem that hinders the development of defense industry is the shortage of narrowly specialized, highly qualified personnel. Defense industry also suffers from decline in human capacity. This is largely due to non-competitive salary and employee benefits, mismatch between the qualification and company's needs, insufficient measures to retain junior personnel. Young people refuse to apply for the jobs in this sector because engineering qualifications are considered low-paid and non-prestigious. Thus, the skills and accumulated experience of long-service employee are lost, more time is needed to master new equipment, 
which is supplied within the frameworks of Federal Target Program. Besides that, there are delays in technical and production processes. All this may create the risk of SDO failure.

An average age of workers in defense industry has increased from 47 to 58. In research institution and organization of defense industry the average age of workers is even higher. Workers under age of 30, according to different estimates, account for 16 to $19 \%$ of the total staff. In research institutes and design studios they account for only $12 \%$ [21].

Thus, it can be concluded that recent changes in the operation of higher education institutes led to the outflow of highly skilled personnel, complication of certification procedures when conferring an academic degree, reluctance to do any research. All this negatively affected research workers and prevented them from realizing their potential.

\subsection{Delays in conclusion of SDO contracts}

There is also another set of problems. Inefficiency of the legal framework for SDO is one of them. Currently, there are a lot of flaws in the regulatory and legal framework of SDO execution: duplication of control function of authorized bodies, lack of proper legal regulation of interaction between banks and general contractor or contractors, the need to introduce criminal liability for violation of the terms of the contracts, misapplication of funds, etc. [22]. Besides, instability of SDO can be caused by pricing issues. Defense industry enterprises face great difficulties because pricing requirements do not consider steadily rising prices of energy, metal, services of infrastructure monopolies, as well as prices charged by OEM suppliers. Instability of SDO can also be caused by the change of economic and political policies.

The solution of these problems will ensure a timely execution of SDO with minimal cost to the state, improve the quality of special equipment, tighten regulations for the execution of state contracts.

\subsection{Pricing problems}

Despite the transition to market economy, pricing policies were not developed within Russia's defense industry. Price formation is accompanied by a set of problems:

- specific features of product costing;

- production accounting procedure;

- calculation of labor intensity with insufficient transparency of legal and regulatory acts.

Calculation of production cost at military-industrial enterprises has its specifics. There are some financial restrictions imposed by government contracts. The most important problem of pricing formation is calculation of proportion of labor used in military goods production. Moreover, it is noteworthy that the enterprises of defense industry have high mobilization costs. Khorev and Goreva state, that they account for $36 \%$ of the total productive capacity of defense industry [18]. Maintenance of defense industry enterprises and insurance of their mobilization capacity require 4-5 billion rubles annually. It is equal to annual investment in machinery and equipment of the given sector. In fact, enterprises get not more than $10 \%$ of this sum. All this does not stimulate defense industry corporations to increase workforce productivity and boost their operational efficiency.

\subsection{Conversion and diversification problems at military-industrial complex enterprises}

Currently, defense industry has two priorities: diversification and increase of civilian production. During the meeting concerning the diversification of civilian goods produced by 
defense industry, President of Russia Vladimir Putin underscored that it is necessary to shift to production of civilian goods or, at the very least, to ensure its quality and competitiveness. According to the head of state, the share of these products in defense industry must be equal to $30 \%$ by 2025 , and $50 \%$ - by 2030 [25]. Besides that, it is necessary to analyze the limitations which prevent the diversification of arms industry, even when conducting public procurement, and then make a starting order, which will allow enterprises to enter the initial stage of production diversification.

It is estimated that local companies will be able to use accumulated experience, scientific, technical and production capacities to produce their own civilian products rather than import them from abroad [23]. However, we cannot say with certainty, whether defense industry enterprises consider civilian products to be of vital importance for them or not. Some defense industry enterprises produce civilian goods which are in great demand among consumers and occupy a leading position in the market. For others civil market is rather unstable. This leads to a lower quality of products and production inefficiency in general. However, it is obvious that reduction of military production to a critical level is unacceptable. That is why, high-tech military products ought to be produced along with civilian products.

During the International Forum on Renewable Energy ARWE it was said that in 2018 the share of civilian goods in the total production volume of the Russian defense industrial complex accounted for $18 \%$. In 2019, the share of civilian products manufactured by defense industry accounted for $21 \%$ [27].

\subsection{Sanctions}

The Ukrainian crisis and imposition of US sanctions against Russia had a negative impact on the development of the Russian DIC. Economic sanctions primarily affected such large defense concerns as "Almaz-Antey", "Sirius", "Stankoinstrument", "Kalashnikov", "Tula Arms Factory", NPO "Vostochnye Kompleksy". Prohibition of debt financing affected such enterprises of defense industry as "Uralvagonzavod", "Oboronprom", "UAC". Western European countries, Japan, Canada, Australia, New Zealand soon joined US sanctions. They imposed ban on export of technological items and supply of dual-use goods. This, undoubtedly, prevents the modernization of defense industry, restoration of its innovative potential to the level of defense sufficiency. In addition, Ukraine stopped selling components, which were used in the space industry, to Russia. This created some difficulties in SDO's execution, as it includes 3 thousand items which are supplied by Ukraine [24, 28].

In September 2018, the USA expanded sanctions against Russia's defense industry. The State Department added 27 individuals and 6 organizations into the "blacklist". According to US authorities, these entities were linked to Russia's defense industry.

Imposition of sanctions has shown that is very difficult to ensure the sustainable economic growth without having your own scientific and technical base, and the industries which would allow the production of high-tech goods. That is why, Russia's government should launch the production of such goods within the country. To do this, it is necessary to identify priorities for import substitution and focus on the production of strategically important goods. Low competitiveness of certain goods, components, etc. may create new problems such as loss of quality, the rise of production costs.

However, under sanctions pressure some problems may arise in import substitution policy:

- Russia's defense industry is not yet prepared to produce goods without importing the necessary components. In order to build new production facilities of the appropriate technological level significant financial investment is required.

- Promotion of import substitution will negatively affect social services such as education and health care due to the cash outflow [24]. 


\subsection{Import dependency}

Russia's defense industry grew increasingly dependent on import of components during the 1990s. It is also dependent on the import of electronic components for its military equipment. Russia imports primarily avionics, aircraft engines, electronics and other electronic products, new generation composites.

In 2011-2012, dependence of Russian defense industry on foreign components was estimated at $80-85 \%$. We have already said that sanctions imposed on import of military and dual-use goods to Russia in 2014 had a profound impact on the defense industry. Sanctions took effect in 20152016 due to exhaustion of the resources and expiration of the contracts signed with the Western countries before the imposition of sanctions. As the large number of components were imported from Ukraine, it was difficult to find an alternative. In 2015 Minster of Defense Sergey Shoygu ordered to master the production of 695 (out of 1070) weapons and equipment samples which were previously produced in collaboration with Ukrainian enterprises. However, in the first half of 2015 only 57 Ukrainian components were replaced instead of the planned 102 items. It accounted for $55 \%$ of annual plan [24].

Such import substitution policy became a serious challenge for defense industrial complex of the Russian Federation. Nevertheless, it can be a good opportunity to increase production capacity despite the reduction of military budget in the coming years.

\subsection{Dependence on the export of arms and military equipment}

Russia's defense industry is one of the largest arms exporters and is ranked the second after the USA. Being an exporter of military equipment, Russia cooperates with 116 countries. In 2019, Rosoboronexport order book exceeded $\$ 50$ billion (the terms of contracts ranged from 3 to 7 years). According to SIPRI, for the period from 2011 to 2018 Russia's export of military equipment accounted for $24.2 \%$ ( $\$ 55.9$ billion to $\$ 231$ billion of the total market volume) of the total world export. Thus, companies which are engaged in export of components and military equipment depend on the demand for their products among both local and foreign consumers. Among top five consumers of Russian weaponry in 2019-2019 were: India 20.3\%, Algeria $10.2 \%$, China 18.6\%, Egypt $14.0 \%$, Iraq 6.0\% [29]. By exporting advanced models of its weapons, Russia contributes to the development of the military-industrial complex of other countries, for example, China and India [30-31].

Thus, in times of political and economic tensions and sanctions pressure on Russia's defense industry, its enterprises are becoming dependent on arms export. To alleviate the burden of crises, falling demand for military equipment among foreign partners, defense industry companies have to expand, develop and produces goods not only for export but also for other needs.

\section{Conclusions}

Arms industry is certainly one of the most important economic sectors that no country can do without. In the modern world, military industrial complex (Russia's defense industry) plays an important role for economic development of a large country. Since Soviet times, Russia's defense industry has been a driving force of Russian economy. Armaments 2020 priority procurement program was designed to reform and modernize Russian defense industry. Some progress was undoubtedly made in achieving these goals [32]. The majority of enterprises of defense industry demonstrated a total growth of financial indicators. Absolutely all companies have positive dynamics in increase of their assets value.

At the same time, restructuring of defense industry revealed some problems which Russia faced during the implementation of Armaments 2020 priority procurement program. 


\section{References}

1. Trauschweizer, I. (2016). Military-Industrial Complex? Armor in Europe and North America after the Second World War. Journal of Military History, 80(1), 296-298.

2. Dunlap, Ch.J. (2011). The Military-Industrial Complex. Daedalus, 140(3), 135-147.

3. Calvo Rufanges, J. (2016). The Arms Industry Lobby in Europe. American Behavioral Scientist, 60(3SI), 305-320.

4. Tulyakova, I. (2008). Transformation of Defense-Industrial Complexes: Experience of Developed Countries and the Russian Way. Globalizácia Jej Sociálno-Ekonomické Dôsledky 08, Zbornik z medzinarodnej vedeckej konferencie. I-II čast` (pp. 585-589). Žilina: University of Zilina.

5. Tulyakova, I.R. (2011). Current State and Prospects of Military-Technical Cooperation with Foreign Countries Russia. Ekonomicko-Manažérske Spektrum, 1, 48-55.

6. Tulyakova, I.R. (2016). The United States and Russia on the Global Arms Markets. Globalization and its Socio-Economic Consequences, 16th international scientific conference proceedings. PTS I-V (pp. 2236-2244). Žilina: University of Zilina.

7. Tulyakova, I.R., Gregova, E., Dengov, V.V. (2017). Assessment of Competitiveness of Shipbuilding Industry in Russia. Nase More, 64(3), 112-119.

8. Dengov, V.V., Tulyakova, I.R., Gregova, E. (2018). Military-Technical Cooperation of Russia in the Context of Globalization: Experience of Cooperation with China. Globalization and its Socio-Economic Consequences, 18th international scientific conference proceedings. PTS I-V (pp. 78-86). Žilina: University of Zilina.

9. Tulyakova, I.R., Dengov, V.V. (2018). Military-Technical Cooperation of Russia in the Context of Globalization: Experience of Cooperation with India, Globalization and its Socio-Economic Consequences, 18th international scientific conference proceedings. PTS I-V (pp. 1401-1408). Žilina: University of Zilina.

10. Tulyakova, I.R., Dengov, V.V., Gregova, E. (2019). The Positions of Russia and Croatia Shipbuilding Products on World Markets and Prospects of Co-operation (Analytical Overview), Nase More, 64(3S), 13-21.

11. Ob utverzhdenii gosudarstvennoj programmy Rossijskoj Federacii. Razvitie oboronnopromyshlennogo kompleksa: Postanovlenie pravitel'stva RF ot 16 maya 2016 goda № 425-8. GOVERNMENT.RU. (2020, March 25). Retrieved from: http://government.ru/rugovclassifier/859/events/

12. O vnesenii izmenenij v gosudarstvennuyu programmu Rossijskoj Federacii. Razvitie oboronno-promyshlennogo kompleksa: Postanovlenie pravitel'stva RF ot 31 marta 2017 goda № 401-15. GOVERNMENT.RU. (2020, March 25). Retrieved from: http://government.ru/docs/27110/

13. Bradshaw, M., Connolly, R. (2016). Barrels and bullets: The geostrategic significance of Russia's oil and gas exports. Bulletin of the Atomic Scientists, 72 (3SI), 156-164.

14. Russian Federal State Statistics Service. (2020, March 25). Retrieved from: https://gks.ru/folder/11189; https://www.gks.ru/storage/mediabank/tab4(2).htm

15. World Bank Open Data. (2020, March 25). Retrieved from: https://data.worldbank.org/indicator/GB.XPD.RSDV.GD.ZS; https://data.worldbank .org/indicator/NY.GDP.MKTP.CN

16. Poslanie Prezidenta Federal'nomu Sobraniyu ot 1 dekabrya 2016 goda. KREMLIN.RU. (2020, March 25). Retrieved from: http://www.kremlin.ru/events/ president/news/53379 
17. Gosudarstvennye programmy vooruzheniya Rossii. Dos'e. TASS Russian News Agency. (2020, March 25). Retrieved from: https://tass.ru/info/4987920

18. Khorev, V., Goreva, O. (2013). Sostoyanie i tendencii razvitiya finansovoekonomicheskogo bloka Vooruzhennyh Sil Rossijskoj Federacii. Armiya i obshchestvo, 3(35), 70-81.

19. Kokhno P., Sitnikov, S. (2013). Priority Directions and Technological Tendencies of Defense Industry Complex. Scientific Bulletin of the Military-Industrial Complex of Russia, 2, 31-40.

20. Kovbasa, N. (2011). Problemy oboronno-promyshlennogo kompleksa Rossii v usloviyah rynochnoj ekonomiki. Nacional'nye interesy: prioritety $i$ bezopasnost', 37(130), 64-68.

21. Voenkova, N. (2015). Aktual'nye problemy razvitiya oboronno-promyshlennogo kompleksa (OPK) Rossijskoj Federacii i puti ih resheniya. Ekonomicheskie strategii, 8, 74-77.

22. Dalekin, P. (2018). Problems of Legal Support of Implementation of the State Defensive Order by the Enterprises in Russian Federation. YUridicheskaya nauka i praktika: Vestnik Nizhegorodskoj akademii MVD Rossii, 1,143-147.

23. Petrova, I., Olshansky, D. (2016). The Conversion of the Russian Defense Industry: Achievements, Problems and Prospects. Economy and entrepreneurship, 10(2), 122-127.

24. Serdyuk, R. (2014). Vliyanie ekonomicheskih sankcij na deyatel'nost' oboronnopromyshlennogo kompleksa. Ekonomika i upravlenie v XXI veke: Tendencii razvitiya, 19(1), 7-12.

25. Soveshchanie po voprosam diversifikacii proizvodstva produkcii grazhdanskogo naznacheniya organizaciyami OPK ot 24 yanvarya 2018 goda. KREMLIN.RU. (2020, March 25). Retrieved from: http://kremlin.ru/events/president/news/56699

26. Research and development expenditure (\% of GDP). The World Bank. (2020, March 25). Retrieved from: https://data.worldbank.org/indicator/GB.XPD.RSDV.GD.ZS

27. Dolya grazhdanskoj produkcii v OPK v 2019 godu sostavlyaet 21\%. Forum po vozobnovlyaemoj energetike ARWE - 2019. TASS Russian News Agency. (2020, March 25). Retrieved from: https://tass.ru/ekonomika/6458530

28. Badrak, V. (2010). Export Oriented the Armaments Complex, Politics, and the Market. OSTEUROPA, 60(2-4), 287-+.

29. SIPRI Military Expenditure Database. Stockholm International Peace Research Institute. (2020, August 8). Retrieved from: http://armstrade.sipri.org/armstrade/html/ export_values.php.

30. Bitzinger, R.A. (2015). Comparing Defense Industry Reforms in China and India. Asian Politics \& Policy, 7(4), 531-553.

31. Liu, SQ, Jiang, YW, Ye, K. (2014). Research on the Motivation of Conventional Weapons Exporting-Empirical Analysis Based on Panel Model, 4th International Conference on Applied Social Science, PT 1, Book Series: Advances in Education Research, vol. 51(pp. 65-71). Singapore: SINGAPORE.

32. Kosals, L., Izyumov, A. (2011). The Russian Defence Industry Confronts the Market: Findings of a Longitudinal Study. Europe-Asia Studies, 63 (5), 733-756. 